\title{
Pre-Service Teachers' Perceptions of the Teaching Principles and Methods Course: Metaphor Analysis
}

\author{
Hanife ESEN AYGÜN*
}

\author{
Çiğdem ŞAHİN TAŞKIN**
}

\begin{abstract}
Teaching Principles and Methods is an important course regarding the quality of teacher education which enables pre-service teachers to gain knowledge and skills about teaching. Through this course, learning outcomes, the roles and activities of teachers and students are clearly defined. Besides, it enables teachers to follow a planned and goal oriented pedagogical path. In this study, pre-service teachers' perceptions of Teaching Principles and Methods course were examined through the metaphors. A phenomenological research design is used in this research. The participants were selected through criterion sampling. In this respect, pre-service teacher enroll the Teaching Principles and Methods Course was considered as a criterion in the fall semester of 2018-2019 academic year. Thus, 117 pre-service teachers from the second year of Basic Education Department participated in the study. Pre-service teachers were asked to respond to the phrase "Teaching Principles and Methods are similar to .... because this is like .....". Thus, pre-service teachers produced variety of metaphors to explain the Principles and Methods Course. Findings obtained from this research revealed that three main categories were emerged through the data analysis. They were named as: The Function of Teaching Principles and Methods Course, The Structure of Teaching Principles and Methods, and the Importance of Teaching Principles and Methods Course
\end{abstract}

Keywords: Teaching Principles and Methods Course, teacher training, pre-service teacher, metaphors.

\footnotetext{
* Orcid ID: https://orcid.org/0000-0001-9363-7083, Assist. Prof. Dr., Çanakkale Onsekiz Mart University, Educational Sciences Department, hanifeesen@comu.edu.tr, Turkey

** Orcid ID: https://orcid.org/0000-0002-6341-5380, Prof. Dr., Çanakkale Onsekiz Mart University, Basic Education Department, csahin@comu.edu.tr, Turkey
} 


\section{INTRODUCTION}

Learning is a process that starts in the family and continues throughout life. However, an individual's learning effort is an existential phenomenon (Biesta, 2015; Camadan, 2018; Duman, 2013; Russell, 2007). Although the definition of learning changes over time, the question of how learning takes place remains current (Bouton, 2000; Brandon \& All, 2000; Domjan, 2014; Fosnot \& Perry, 2005; Güneş, Sağdıç \& Şimşek, 2018; Eisenhardt \& Menzel, 2007; Richardson, 2005 ). Accordingly, the impact of the factors that play a role in learning continues to be studied (Bråten, McCrudden, Stang Lund, Brante and Strømsø, 2018; Homer, Hew and Tan, 2018). To date, there are many factors that play a role in effective learning such as different learning needs and student profile (Açlkgöz, 2005; Başaran, 2004; Özer, 2005). Determination of appropriate teaching methods and techniques for students is closely related to the professional competencies of the teacher (Teaching Profession General Competencies, 2017). In this context, the teaching principles and methods course, which is included in education faculty undergraduate programs, has an important place in the development of the professional competencies of the pre-service teachers in terms of introducing models, strategies, methods and techniques that contribute to the creation of an effective learning process.

The teaching principles and methods course includes basic concepts related to this course; teaching-learning principles, models, strategies, methods and techniques; setting goals and objectives in education; content selection and organization in teaching and learning; teaching materials; teaching planning and teaching plans; theories and approaches about teaching; success in teaching, learning and learning in effective school; and in-class learning topics (Higher Education Council [YÖK], 2018). However, this course is not only in Turkey, though it is seen that take place with different names in teacher education programs in different countries (Kanuka, Rourke \& Laflamme, 2007; Mergendol, Maxwell \& Bellisimo, 2006; Orlich, Harder, Callahan, Trevisan \& Brown 2012; Young, Klemzn \& Murphy, 2003). The quality regulation of the teaching-learning process in the realization of effective learning is an international competence area in terms of teaching profession (Yavuz, Özkaral \& Ylldı, 2015) because how the teacher explains is as important as what the teacher tells (Şahin-Taşkın \& Hacıömeroğlu, 2009). One of the courses that the trainee will acquire knowledge and skills about what and how to explain is the teaching principles and methods course (Yeşilpınar-Uyar, 2016). According to Williams (2002), students who are active and know various teaching strategies are more effective in the learning-teaching process. Through this course, learning outcomes, roles of teachers, and students and activities are clearly defined, and a planned and purposeful pedagogical path is followed (Kanuka, Rourke, \& Laflamme, 2007). Accordingly, it is thought that learning the perceptions of pre-service teachers towards the teaching principles and methods course will make this course more functional for the pre-service teachers, thus contributing to the more qualified functioning of the course and thus to the professional competence acquisition of pre-service teachers.

Researchers frequently used metaphors to examine participants' perceptions about a topic. Although metaphors reflect the experiences of individuals (Miller, 1987), it deals 
with how information and emotion are handled (Wagener, 2017). With this aspect, it is defined as an important research tool in grasping and explaining mental images (Saban, 2009). Metaphors fulfil this mediating role by deeply understanding concepts (Tiryaki \& Demir, 2016). Metaphors, a mental model, thus help to establish a deep connection with concepts (Dur, 2016). Also, it is known that the metacognitive system is actively used in producing metaphors (Tiryaki \& Demir, 2016).

When the literature is examined, it is seen that the pre-service teachers' perceptions about concepts such as teaching and learning (Altay \& Tekinaslan, 2013; Aydın \& Pehlivan, 2010; Çulha-Özbaş \& Aktekin, 2013; Işık, 2014; Kalyoncu, 2012; Pektaş \& Kıldan, 2009; Koç, 2014; Saban, 2004; Saban, 2009; Saban, Koçbeker \& Saban, 2006; Saban \& Keleşoğlu, 2011; Tortop, 2013; Yalçın-Wells, 2015; Yılmaz, Göçen, \& Yllmaz, 2013), education (Altun \& Apaydın, 2013), curriculum (Aykaç \& Çelik, 2014; Gültekin, 2013; Özdemir, 2012), curriculum development (Göğebakan-Yıldız, 2017; Semerci, 2007), which are among the basic concepts of teaching principles and methods, are examined. However, teaching principles and methods include the concepts of learning and teaching, education, curriculum development and curriculum as well as many more. For this reason, it is considered that determining the perception of the course itself through metaphors rather than a single concept is important in terms of increasing the quality of the course. As mentioned above, metaphors are an important tool in understanding and comprehending individuals' perceptions about a subject (Jensen, 2006). Accordingly, examining preservice teachers' perceptions about the teaching principles and methods course through metaphors will contribute to pre-service teachers in terms of developing creative thinking skills in teacher education. In addition, metaphors offer an innovative perspective in providing alternative solutions to educational problems (Çelikten, 2006). When the literature is examined, it is seen that some studies have been carried out about the teaching principles and methods course, which is given at the beginning of teacher education and which is very important in terms of professional knowledge. For example, it is observed that studies related to the teaching principles and methods course are generally associated with academic success (Tan, 2010); the ability of pre-service teachers to use this course (Öztürk, 2004; Kuzu ve Demir, 2015; Soylu, 2009); the needs analysis related to this course (Yeşilpınar-Uyar, 2016), the opinions (Ylldırım ve Demir, 2016); and the evaluation (Yeşilpınar-Uyar ve Doğanay, 2017) and determination of the effectiveness of pre-service teachers regarding the teaching principles and methods course prepared according to different features (Yeşilpınar-Uyar ve Doğanay, 2018). However, it is understood that pre-service teachers' perceptions of this course have not been studied before. Considering the statement of "encouraging students to think at a higher level", which is stated by the General Directorate of Teacher Training and Development (Ministry of National Education [MoNE], 2017) as a professional skill, it is another expression of the pre-service teachers' handling of a case with the help of another phenomenon. It is thought that producing metaphors is important for professional development. Accordingly, in this study, it was aimed to examine pre-service teachers' 
perceptions about teaching principles and methods through metaphors. The subobjectives are determined as follows:

- Determining pre-service teachers' perceptions about teaching principles and methods,

- To obtain information about how to help pre-service teachers to teach teaching principles and methods in a qualified way.

\section{METHOD}

\section{Research Design}

In this research, phenomenology, one of the qualitative research patterns, was used. In studies designed with phenomenology, it is aimed to obtain information about the personal experiences of individuals about a phenomenon (Creswell, 2007). Thus, meanings that individuals attribute to a phenomenon are reached by means of experiences (Merriam, 2009). Therefore, the starting point of the phenomenological research is the experiences of participants (Ersoy, 2016). In this study, phenomenology was used since the participants' perceptions about this course were examined through metaphors based on their experiences of teaching principles and methods.

\section{Participants}

Considering the purpose of the research, it was thought that it was possible for the preservice teachers to produce appropriate metaphors about the teaching principles and methods course by having sufficient knowledge about this course. For this reason, criterion sampling from the purposeful sampling method, which allows the selection of individuals with certain predetermined features, was used in the creation of the study group (Patton, 2014). Accordingly, that pre-service teachers were taking the teaching principles and methods course was determined as a criterion.

The pre-service teachers who attended the study in the third semester of the Basic Education Department and still take the teaching principles and methods course, participated in the research. The data were collected in the $12^{\text {th }}$ week of the 14 -week period. Thus, in the data collection process that coincided with the last weeks of the semester, the pre-service teachers were provided with sufficient knowledge of teaching principles and methods. The study group was limited to the second year students enrolled in the course as it was thought that prospective teachers would help them to explain their perceptions of teaching principles and methods more vividly and clearly. Accordingly, 117 pre-service teachers attending the second grade of the Basic Education Department of a public university in the Marmara Region participated in the research in the fall semester of the 2018-2019 academic year (Table 1). The identities of the pre-service teacher who participated in the research were kept confidential. For this reason, each pre-service teacher who participated in the study was numbered and coded (For example; S012 and 000102). 
Table 1

Demographic Features

\begin{tabular}{|c|c|c|c|c|}
\hline Department & Female & Male & Total & Percent \\
\hline $\begin{array}{l}\text { Primary } \\
\text { Education }\end{array}$ & 42 & 35 & 77 & 65.8 \\
\hline Pre-school Education & 31 & 9 & 40 & 34.2 \\
\hline Total & 73 & 44 & 117 & 100 \\
\hline
\end{tabular}

When Table 1 is examined, it is understood that 77 pre-service teachers were in Primary School Education and that 40 of them were in Preschool Education Department. While $65.8 \%$ of pre-service teachers study in the department of primary school education, $34.2 \%$ of them study in the department of preschool education. In addition, 73 of preservice teachers participating in the research are female and 44 are male.

\section{Collecting Data}

The data were collected in the $12^{\text {th }}$ week of the fall semester of the 2018-2019 academic year from the pre-service teachers who study in the department of primary school education and preschool education. Data collection was carried out immediately after the teaching principles and methods course taken by the pre-service teachers. Volunteering was based on participation in the research. Pre-service teachers were given information primarily for the purpose of the research. "The teaching principles and methods course... .. similar from the candidates. Because... .. "were asked to respond to the statement. Data collection took about twenty minutes. In addition, the teaching principles and methods course in the departments of primary school and preschool education was conducted by different lecturers. Accordingly, that the way instructors conduct the course might affect the opinions of pre-service teachers can be considered as a limitation. However, the data were analysed by taking this into account.

\section{Data Analysis}

In qualitative research, metaphors are used either to improve the process or to reveal the current situation as it is (Fırat, Kabakçı-Yurdakul, \& Ersoy, 2014). In this regard, considering the purpose of the research, the teaching principles and methods of the preservice teachers were described as they were through metaphors.

Content analysis approach was adopted in the analysis of the data. First of all, the metaphors produced by the pre-service teachers were thoroughly examined and listed. Then, these metaphors were examined in detail with their individual explanations; weak expressions belonging to 4 pre-service teachers who did not show consistency or did not point to a metaphor, were removed from the data set. Thus, the metaphors of 117 preservice teachers were included in the data set. In the analysis of the data, the common features of the metaphors used by the pre-service teachers were determined. Those of a similar nature were grouped. In other words, the metaphors were categorized in terms of their features. For example; similar expressions such as guide-compass-guide-map and 
guiding light-flashlight were grouped from the metaphors used by the pre-service teachers. Then, categories were created from these expressions by means of meaning sets. In line with the pre-service teachers' metaphors and explanations, this category was called Becoming a Guide. Thus, three main categories were obtained. According to the intensity of the pre-service teachers to produce metaphors, 2 to 4 examples were presented in the findings section. These categories were named as The Function of the Teaching Principles and Methods course, The Structure of the Teaching Principles and Methods Course, and The Importance of the Teaching Principles and Methods Course.

\section{FINDINGS}

The findings obtained from this research show that the pre-service teachers perceive their perceptions about teaching principles and methods in three main categories: the function of teaching principles and methods, the structure of teaching principles and methods, and the importance of teaching principles and methods. The diagram showing the findings obtained from the research is given in Figure 1:

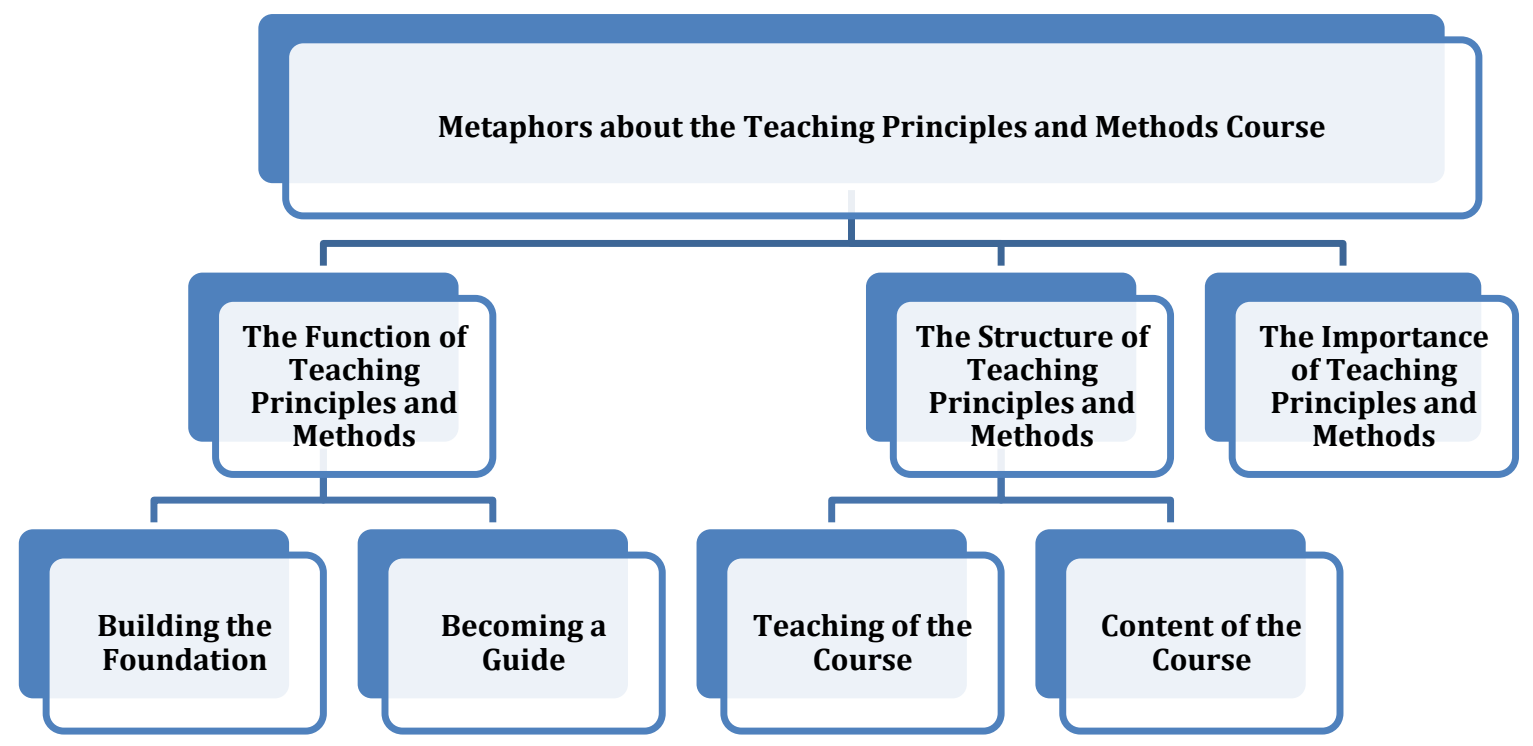

Figure 1. Categorical Structure

When Figure 1 is examined, it is seen that the metaphors of the pre-service teachers are gathered in 3 main categories. The function of the teaching principles and methods course from these categories includes building the foundation and becoming a guide, while the structure of the teaching principles and methods course consists of the subject of the teaching of the course and the content of the course.

The Function of Teaching Principles and Methods 
It is observed that the metaphors under this category reveal that information learned in this course is the basis for the subjects to be learned in other courses and will guide them when they become teachers. In line with these explanations, the metaphors of the prospective teachers' teaching principles and methods course are explained below in two sub-categories: building the foundation and becoming a guide.

\section{Building the Foundation}

In this category, the pre-service teachers mostly used alphabet metaphor; however, while explaining the function of the course, it is seen that some pre-service teachers used the metaphors of the foundation of a building; bee; building blocks; and a cog in a machine. It is understood from the metaphors used by the pre-service teachers that they see the teaching principles and methods course as the basis of teacher education. Pre-service teachers' metaphors and their explanations about these metaphors are as follows:

- $\quad$ The teaching principles and methods course is similar to learning the alphabet because the basis and beginning of everything (learning, teaching, teaching learning) begins with this course ( SO 17)

- The teaching principles and methods course is similar to the foundation of a building because I think it is the basis for performing the teaching and the stronger we lay the teaching foundation, the more permanent and effective it becomes (SO 28)

- $\quad$ The teaching principles and methods course is similar to a teacher's building blocks because a teacher cannot provide an efficient education without taking this course (000 98)

- The teaching principles and methods course is similar to a cog in a machine because it is the cogs that rotate the building blocks of a system, and this course is the building blocks of education since, when these cogs are broken or stopped, the machine will not work; so, the importance of this course occurs in the education system in this way (000 112)

The primary school teacher candidates SO 17 and SO 28 and the pre-school teacher candidates 00098 and 000112 explained their perceptions about the foundation, building block and cog-in-a-machine metaphors and teaching principles and methods. SO 17 explained this course with alphabet metaphor. He emphasized that literacy learning started with learning the alphabet and that the alphabet was, therefore, a kind of foundation. He stated that this course was the basis and beginning of being able to teach. When the descriptions of pre-service teachers SO 28 and 00098 are examined, it is seen that they emphasize that this course supports permanent, effective and efficient learning. 00012 emphasized that this course had an important place in the education system and stated that education was one of the building blocks. Unlike these explanations, the following pre-service teacher explained the teaching principles and methods course with a bee metaphor: 
- $\quad$ The teaching principles and methods course is similar to bee because we collect the information first in ourselves and then distribute it, just like honey (000 86)

00086 stated that he would distribute the information gained in this course to its students in the future like a bee collecting flower dust and producing honey. This statement of the teacher candidate can be interpreted as such: the basis of making honey is to collect flower dust, and the basis of teaching is to learn a lot from this course effectively. The pre-service teachers' explanations regarding becoming a guide subcategory are as follows:

\section{Becoming a Guide}

The metaphors stated by the pre-service teachers indicate that they see the teaching principles and methods course as a guiding element in the teaching profession. When the findings are examined in detail, it is seen that most of pre-service teachers in the becoming a guide subcategory explain the teaching principles and methods course with the teacher metaphor:

- $\quad$ The teaching principles and methods course is similar to a teacher because in this course it teaches how to behave to a child, how we can convey information to them in the most correct way, and how a teacher should be very careful about these issues (SO 33)

- The teaching principles and methods course is similar to a good teacher because it teaches how to become a well-equipped teacher (000 102)

- The teaching principles and methods course are similar to the masterapprentice relationship because the teacher, who has a great deal of theoretical and practical knowledge about the course, tries to transfer all his knowledge to us who will do the same work in the future (SO 9)

- The teaching principles and methods course is similar to a mother because, when she raises her child, she applies the rules she adopts in her own way, just as those principles, methods and rules applied by the teacher in the teaching principles and methods course (SO 14)

The teaching principles and methods course is similar to a mother because it guides us through what we might face with in our life problems and helps us to do what we should, and teaches us the things we can frequently use in our professional life (SO 56)

The pre-service teachers above stated that this course was similar to the teacher, mother and master-apprentice relationship. For example, SO 33, using the teacher metaphor, stated that he learned how to approach to a child and transfer information. SO 9, who used the metaphor of the master-apprentice relationship, emphasized the transfer of information in a similar way, although he used a different metaphor than the teacher candidate above. These statements indicate that pre-service teachers see the teacher at the centre of learning. It is known that the direct transfer of information and behavioural 
goals are at the forefront in the approaches where the teacher is at the centre of learning (Bulut, 2008; Yalçın-İncik \& Tanrıseven, 2012). Similarly, 000 102, using the metaphor of the teacher, emphasized that the teacher would be equipped thanks to this course. This statement of he pre-service teachers is thought to be related to the teacher gaining professional competencies. When the General Competencies of Teaching Profession (2017) are examined, it is seen that the skills of planning and learning environments, which are within the scope of professional skills, are related to the subjects learned in the Teaching Principles and Methods course. On the other hand, while explaining the teaching principles and methods course with the mother metaphor, SO 14 and SO 56 emphasized the rules adopted by the mother in raising her child and helping her child. It is understood from this statement that the pre-service teachers consider the mother as a person who is interested in the care of children. The following pre-service teachers explained this lesson with the metaphors of prescriptions, guides and compass:

- $\quad$ Teaching principles and methods are similar to prescribing because this course is similar to prescribing in terms of how the teacher should teach the course and its aims and techniques (SO 52)

- $\quad$ The teaching principles and methods course is similar to the guide because it conveys what the guide is, how it is and what is right, and I think the guide of a teacher is this lesson (SO 53)

The teaching principles and methods course is like a compass because it tells us how to teach children and guides us to convey information (000 113)

When the pre-service teachers' explanations are analysed, it is seen that they stated how the teaching principles and methods course should teach the course to students. These metaphors show that the pre-service teachers see this course as a guide and think that this course will guide them in their teaching life. Therefore, it is thought that they care about teaching principles and methods in order to be a good teacher in terms of professional qualifications. Unlike the opinions of the above pre-service teachers, SO 51 and 00097 used the football academy and sportive strategies metaphors:

The teaching principles and methods course is similar to football academy because they teach how to hit the ball first rather than how to score goals in the infrastructure, along with how to fall, defend and use energy correctly; football consists of methods and strategies in itself just like this course (SO 51)

- $\quad$ The teaching principles and methods course is similar to sportive strategies because, in sports, if you do not have a technique, you cannot beat your opponent, take the lead and enjoy the sport you do; we see the use of different methods in this course and I therefore think that it looks like it (000 97)

When the pre-service teachers examine the explanations above, it is seen that they explain the teaching principles and methods course by comparing it to sports activities. For example, SO 51 compared this course to football academy and explained this 
interpretation by pointing out that the most basic things taught in football academy were methods and strategies. Similarly, 00097 explained the metaphor of sportive strategies by using the concepts of tactics, technique and method. It is thought that these preschool teachers, who used the concepts of tactics, technique, method and strategy in their explanations, emphasize the concepts of strategy, method and technique that are covered within the course of teaching principles and methods.

When the expressions related to the becoming a guide subcategory are evaluated in general, it is seen that the most frequently repeated metaphor is the teacher metaphor. However, when the pre-service teachers' metaphors are examined considering the department they study, it is seen that the concept of mother is used only by the primary school teacher candidates. In addition, it was understood that the primary school teacher candidates frequently used parent and family metaphors related to the mother. Of the preservice teachers who participated in the study, only male pre-service teacher used metaphors related to football or other sports.

\section{The Structure of Teaching Principles and Methods}

The pre-service teachers' metaphors in this category include explanations about how they perceive the content of the course and how they evaluate the course's handling. In this direction, the findings were examined in two sub-categories: the content of the course and the teaching of the course.

\section{The Content of the Course}

In this sub-category, most of the pre-service teachers explained the content of the teaching principles and methods course with the pomegranate metaphor. Pre-service teachers also used metaphors such as seeds, trees, grapes and onions to explain the content of the course. These metaphors used by the pre-service teachers show that they perceive the content of the course as piece-whole and intertwined. Some of the participants' views are as follows:

- $\quad$ The teaching principles and methods course is similar to pomegranate because how the lesson turns into a whole constitutes the basis of all teaching; and since they are generally taught in teaching methods and techniques, they are seen as the basis of teaching (SO 26)

- The teaching principles and methods course is similar to grape bunches because when grape grains come together, it forms the bunches, that is, teaching theories and models, teaching strategies, teaching methods, teaching techniques, etc. If we accept the subjects from grape grains, when all the issues come together, it forms the grape cluster, that is, the teaching principles and methods course (SO 34)

When pre-service teachers' expressions above are examined; it is understood that they see each subject learned in this course as a meaningful part that constitutes the whole. For example, SO 26 using the pomegranate metaphor stated that it constituted the whole parts and that this was the basis of teaching. SO 36 stated that, as a result of the grape 
grains coming together, they formed the grape bunches. It is understood in the explanations of pre-service teachers that they talk about the content of this course. However, some pre-service teachers explained the teaching principles and methods course by using seed and tree metaphors:

- $\quad$ The teaching principles and methods course is similar to seed because the main element that enables a plant to exist is the seed, while the main element for a teacher to become a teacher is this course; if there is no seed, there is no plant ( SO 46)

- $\quad$ The teaching principles and methods course is similar to a tree because when you water it, you develop more strategies; and when you develop different strategies, you get more crop (000 117)

The idea of productivity should be underlined in the explanations of pre-service teachers using seed and tree metaphors. For example, SO 46 stated that there would be no plants if there were no seeds and SO 56 stated that tree would bear fruit as a result of good nutrition of the tree, while 000117 stated that more yield would be obtained when the tree was watered. In this regard, it can be said that pre-service teachers think that the teaching principles and methods course has an important place in terms of understanding the psychology of the student, developing different learning strategies and thus raising qualified students. Unlike the others in this category, a pre-service teacher appears to use the onion metaphor:

- $\quad$ Teaching principles and methods are similar to an onion because it has many layers as in the case in which each subject is related to each other (SO 41)

It is seen that the primary school teacher candidate SO 41 compares the course to an onion. In this explanation of the pre-service teacher, it is thought that the issues are based on the relationship with each other. In other words, the pre-service teacher likened the onion to an onion by thinking that each of the topics learned in the course constituted a layer of a structure.

It is noteworthy that the primary school teacher and pre-school teacher candidates have different perceptions about the content of the course in terms of teaching principles and methods. Detailed reviews show that almost all of the metaphors in this subcategory are produced by primary school teacher candidates. It can be seen that only one pre-school teacher candidate produced a metaphor regarding the content of teaching principles and methods. This may be due to the fact that teaching methods used in pre-school education might have a different structure; it can also be caused by the way lecturer give the course.

\section{The Teaching of the Course}

In this sub-category, pre-service teachers used puzzle and sweater metaphors about the teaching principles and methods of the course. Some of the statements of the teacher candidates in this category are as follows:

- The teaching principles and methods course is like a puzzle because this course teaches us how to handle the most appropriate lesson at the right time, just like a 
puzzle in which there is only one piece in a thousand pieces that fits into that part, and it depends on us to find and place that piece (SO 39)

- $\quad$ The teaching principles and methods course is similar to a sweater because the loop is stitched and the end result is a very well combined whole product (SO 63)

When the statements of pre-service teachers are examined closely, it is seen that they associate their views on the course of this course with replacing the right piece at the right time. For example, it is understood from the explanation of SO 39, who uses the puzzle metaphor, that every topic learned in this course has a place and that the subjects will be put in the right place and a whole will be obtained. SO 63, on the other hand, emphasized the idea of joining the pieces in a manner similar to the explanations of SO 39 with the sweater metaphor. Accordingly, it is thought that the opinions of pre-service teachers regarding the way the lesson is taught focus on the whole relationship.

\section{The Importance of the Teaching Principles and Methods Course}

When the metaphors produced by pre-service teachers about the importance of teaching principles and methods course are examined, it is seen that they use water, sun, a long way, life and vitamin metaphors. It is understood from these metaphors used by preservice teachers that they see teaching principles and methods as a vital course for teaching.

- $\quad$ The teaching principles and methods course is similar to the sun because plants need the sun to grow, and thanks to what I learned and will learn in this course, I will try to grow the sun in my small and beautiful flowers (SO 4)

- $\quad$ The teaching principles and methods course is similar to the sunrise because the period when all sides are dark is the period when teachers do not have knowledge about teaching; thanks to this course, the sun rises and the teacher knows himself and his students (SO 69)

In the explanations of pre-service teachers using the sun metaphor, it is seen that the sun is nourishing for plants and lighting. For example, when SO 4 used sun metaphor, it was based on the importance of the sun on plants in explaining this metaphor. He stated that he would grow his students with the help of this course, as the sun fed plants by growing them. Likewise, SO 69 likened teaching knowledge to sunlight and stated that, thanks to this course, the teacher would recognize himself and his students. These explanations reveal that pre-service teachers draw attention to emphasise the importance of this course based on the vital importance of the sun for living things. Some pre-service teachers explained this course with life and path metaphors:

- $\quad$ The teaching principles and methods course is similar to life because in life we have certain strategies and efforts to come to a place where we can live happily (SO 47)

The teaching principles and methods course is like a long way because we are gaining more and more experience on this road, we encounter difficulties, we look at 
the experiences that are left behind as the road progresses, and these are the best details that approach to us towards the end of the road (SO 75)

When the expressions of the pre-service teachers above are examined, it is understood that they compare this course to life itself. For example, while SO 47 talked about the strategies we followed to be happy in life, SO 75 emphasized that this course was a long way, provided progress and helped us to gain experience. These statements of the teacher candidates show that they find the teaching principles and methods course important for the teaching profession. Similarly, 00088 mentioned the benefits of this course by comparing it to vitamins:

- $\quad$ The teaching principles and methods course is similar to vitamin because it helps to be more useful to children (000 88)

In the above statement, 00088 points out that vitamins are beneficial to living things. The pre-service teacher below pointed out that this course was a vital one for the teaching profession by comparing it to water:

The teaching principles and methods course is like water because water is important for life and we cannot live without it; and for a teacher candidate, this course is almost like water and the subjects we learned in this lesson will be very useful in our working life (SO 64)

Based on the importance of water for living things, the SO 64 emphasized that the teaching principles and methods course was vital for teachers like water. When the metaphors stated by the pre-service teachers within the scope of this category are examined, it is understood that they find the teaching principles and methods course very important in teacher education. In addition, they believe in the contribution of this course to improving their professional qualifications.

\section{DISCUSSION}

In this study, where the mental images of pre-service teachers who studying in the Department of Basic Education are examined, the findings show that the pre-service teachers' mental images related to this course are very diverse. 117 pre-service teachers who participated in the research used various metaphors. Although metaphors reflect the experiences of individuals (Miller, 1987); it deals with how information and emotion are handled (Wagener, 2017). Based on this information, interpreting the metaphors produced by the pre-service teachers regarding the teaching principles and methods course through the consideration of their life experiences; it will help to articulate how they perceive this course .

The findings show that pre-service teachers emphasize the basic forming and guiding functions of the teaching principles and methods course. The metaphors that pre-service teachers use for the function of this course, such as alphabets and building blocks, can be interpreted as such: this course lays the foundation for being a teacher. The teaching 
principles and methods course curriculum, which is a vocational course and included in the fourth semester of the PreSchool Education and Primary School Education Program, includes subjects such as "the basic concepts related to teaching principles and methods; teaching-learning principles, models, strategies, methods and techniques; setting goals and objectives in education; content selection and organization in teaching and learning; teaching materials; teaching planning and teaching plans; theories and approaches about teaching; success in teaching, learning and learning in effective school; and evaluation of classroom learning" (Higher Education Council, 2018). Accordingly, it is seen that the teaching principles and methods course includes the subjects that are essential for the preparation of the learning-teaching environment. Similarly, the literature emphasizes that this course has an important place in teacher education in terms of the goal of training qualified teachers (Saracaloğlu \& Karasakaloğlu, 2011). When the General Competencies of Teaching Profession (2017) are examined, a significant part of the skills expected within the scope of the dimensions of planning and teaching education, creating learning environments, and teaching and managing the learning process are presented to prospective teachers within the scope of the course. When the obtained results are evaluated from this point of view, it is revealed that the pre-service teachers' understanding of the principles and methods course as the basis for teaching is understood by the pre-service teachers.

It is understood that pre-service teachers see the teaching principles and methods course in terms of their function in teaching life. When the data are examined closely, it is seen that some pre-service teachers compared this course to the teacher while the others stated that it was possible for the teacher to demonstrate his professional skills with this lesson. Accordingly, it is understood that pre-service teachers associate the teaching principles and methods course with the concept of being a good teacher. As emphasized above, the teaching principles and methods course is a vocational knowledge course aimed at improving teachers' professional competencies (Higher Education Council, 2018). Raising individuals beneficial to the society is related to the competence of teachers (Öztürk, 2004). This course has an important place in giving the teacher the capacity to choose the appropriate method and technique in order to realize an effective learning-teaching process (Saracaloğlu \& Karasakaloğlu, 2011). In this regard, it is understood that the results are similar to the results of previous studies in the literature. For example, it is observed that pre-service teachers use metaphors such as maps, guides and lights that define the teacher as a guide (Koç, 2014). Similarly, it was understood that pre-service teachers studying in different undergraduate programs define the teacher as a guide by using metaphors such as map, compass and guide for the teacher concept (Aydın \& Pehlivan, 2010, Saban, Koçbeker, \& Saban, 2006). In addition, Senemoğlu (2007) defines the task of the teacher in an effective learning environment as determining, organizing, implementing and evaluating the appropriate activities by considering achievements in the curriculum and student characteristics. These explanations highlight the teacher's duty to guide. Similarly, the Ministry of Education (2002) determined the duties of the teacher as to guide learning activities and facilitate learning. In addition, 
when the Regulation on Primary Education Institutions (2014) is examined, it is stated that preschool and classroom teachers are responsible for planning and implementing the education and training activities according to the principles specified in the education and training program. In this regard, it is understood that the opinions of pre-service teachers about the fact that teaching principles and methods course guides the teacher are compatible with both the literature and legislation. In addition, considering the definition of the content of teaching principles and methods within the scope of Teacher Training Undergraduate Programs and the metaphors of the pre-service teachers regarding the function of this course, it is thought that the teaching principles and methods course reached the aim of a significant part of the pre-service teachers participating in this research.

The metaphors of the pre-service teachers on the structure of principles and methods consist of two sub-categories: the structure of the course, the content of the course and the teaching of the course. While the content of the course comes to the forefront from the piece to the whole and the interrelated relationships, it is observed that the focus of the course is similarly focused on the part-to-whole relationship. When the curriculum of the teaching principles and methods course is examined, it is understood that the progressing structure consisting of basic concepts, models, strategies, methods and techniques constitutes a whole from general to specific (Arslan, 2007; Baştürk, 2013; Duman, 2011; Teacher Training Undergraduate Programs, 2018; Tan, 2012). Accordingly, it can be said that the mental imaginations of pre-service teachers towards the structure of the teaching principles and methods course are compatible with the structure of the course. However, the most important situation to be considered in this category is the prevalence of the primary school teacher candidates in both sub-categories. While only one preschool teacher candidate produces metaphors in the content of the course sub-category, all the metaphors produced in the coirse belongs to the primary school teacher candidates. It is thought that this situation may have been caused by various reasons. For example, given the structure of preschool education, it is seen that the themes / topics in the Preschool Education Program are not instruments but rather a purpose. In other words, in preschool education, there is no subject- or theme-centred education in gaining gains and indicators, but various issues can be used while planning the education process. "The main purpose here is not the teaching of the subject, but the achievement of gains and indicators with the help of that subject" (Preschool Education Program, 2013: 16). However, it is seen that basic courses such as Turkish, Mathematics, Life Science, Science and Social Studies in primary school programs are based on subject and theme-centred learning (Primary School Curriculum, 2018). For this reason, primary school teacher candidates who will teach different subjects in many courses can use the strategies, methods and techniques learned in the context of the teaching principles and methods course in different ways in order to address their various learner profiles. In addition, although teaching principles and methods are included in all teacher training programs as professional knowledge, it is understood that the attitudes of pre-service teachers from different teacher training programs to the course are different when examined in the literature (Tan, 2010). 
However, it can be thought that the way the teacher teaches the course and the opinions between the two groups differ.

In the category of the importance of the teaching principles and methods course within the scope of the research, it is seen that pre-service teachers visualize the course as sun, life, road, water and vitamin metaphors. When the pre-service teachers' explanations about the metaphors they use are examined, it is understood that they find the teaching principles and methods course very important in terms of their professional development. Especially the sun and water metaphors and explanations regarding these metaphors point out that pre-service teacher find this course important in terms of effective teaching practice. This situation is similar to the results of various studies. For example, in a study examining vocational knowledge courses in various teacher training programs in different universities, it is understood that prospective teachers find the teaching principles and methods course important (Yalçın \& Şengül-Avşar, 2014). Similarly, in another study, it is seen that pre-service teachers stated that they found the teaching principles and methods course important in terms of enabling the development of competence in the learning-teaching process (Şahin \& Kartal, 2013). In addition, in another study examining the opinions of instructors about the courses in the Pre-School Education program, it is observed that instructors also care about the principles and methods of teaching in terms of the quality of the teaching profession (Dereobalı \& Ünver, 2009). However, although the teaching principles and methods course is found to be important by the pre-service teachers and lecturers teaching this course; studies with teachers point out that active learning given to pre-service teachers in this course is not used effectively in the learning-teaching process. For example, although many researchers care about the teaching principles and methods of primary school teachers, they emphasize that the most used strategy is the way of presentation while the most used method is the method of straight narration and the most used technique is the questionanswer technique (Geçer \& Özel, 2012; Muşta \& Taşkaya, 2008; Ocak, Ocak, Yılmaz, \& Mergen; 2012; Tatar \& Ceyhan, 2018; Yeșilyurt, 2013; Yıldız-Feyzioğlu, 2012). However, as a result of the change in the philosophical basis of educational programs in Turkey in 2005 and the adoption of the constructivist approach, teachers are also expected to use teaching strategies through inventions and research investigations as well as traditional strategies (Ocak, Ocak, Yılmaz, \& Mergen 2012; Sarıkaya, Güven, Göksu, \& İnce-Aka, 2010). According to Tatar and Ceyhan (2018), the teacher-centred lecture tendency is about not having enough information about student-centred methods and techniques and comes from a teacher-entered education system. In this regard, the teaching principles and methods course comes to the fore in order to increase the student-centred courseprocessing competencies of prospective teachers in accordance with the curriculum in Turkey. Teaching principles and methods have been included in teacher training programs in Turkey since 1964 despite the occasional changes in the definition of course definition as a result of the developments in education (Küçükahmet, 2007). It is thought that the need for this course in Turkish National Education for more than half a century is related to the goal of training qualified teachers. Because the teaching principles and 
methods course has an important place in gaining professional competence in terms of providing prospective teachers with the opportunity to connect between using and using theoretical information (Yeşilpınar-Uyar \& Doğanay, 2017). For this reason, it is recommended to conduct detailed studies for the reasons of the difference between theory and practice and to eliminate these differences.

\section{References}

Açıkgöz, K. Ü. (2005). Etkili öğrenme ve öğretme. Ankara: Eğitim Dünyası Yayınları.

Altay, E., \& Tekinarslan, E. (2013). Öğretmen, öğretme, öğrenme, öğretim materyali ve değerlendirmeye ilişkin metaforlar: Yapısal bir analiz. Gaziantep University Journal of Social Sciences, 12(3), 443-467.

Altun, S. A. \&Apaydın, C.. (2013). Kız ve erkek öğretmen adaylarının "eğitim" kavramına iliskin metaforik algıları. Kuram ve Uygulamada Eğitim Yönetimi Dergisi, 19(3), 329-354.

Arslan, M. (2007). Öğretim ilke ve yöntemleri, Ankara: Anı Yayıncılık.

Aydın, İ. S., \& Pehlivan, A. (2010). Türkçe öğretmeni adaylarının öğretmen ve öğrenci kavramlarına ilişkin kullandıkları metaforlar. Turkish Studies, 5(3), 818-842.

Aykaç, N., \& Çelik, Ö. (2014). Öğretmenlerin ve öğretmen adaylarının eğitim programına ilişkin metaforik algılarının karşılaştırılması. Eğitim ve Bilim, 39(173), 326-339.

Başaran, B. I. (2004). Etkili öğrenme ve çoklu zekâ kuramı: bir inceleme. Ege Eğitim Dergisi, 5(1), 7-15.

Baştürk, S. (2013). Öğretim ilke ve yöntemleri, Ankara: Vize Basın Yayın.

Biesta, G. (2015). Freeing teaching from learning: opening up existential possibilities in educational relationships. Studies in Philosophy and Education, 34(3), 229-243.

Bouton, M. E. (2000). A learning theory perspective on lapse, relapse, and the maintenance of behavior change. Health Psychology, 19(1S), 57-63.

Bulut, İ. (2008). Yeni ilköğretim programlarında öngörülen öğrenci merkezli uygulamalara ilişkin öğretmen görüşleri (Diyarbakır ili örneği). Kuram ve Uygulamada Eğitim Yönetimi Dergisi, 14(4), 521-546.

Brandon, A. F., \& All, A. C. (2010). Constructivism theory analysis and application to curricula. Nursing Education Perspectives, 31(2), 89-92.

Bråten, I., McCrudden, M. T., Stang Lund, E., Brante, E. W., \& Strømsø, H. I. (2018). Task-oriented learning with multiple documents: effects of topic familiarity, author expertise, and content relevance on document selection, processing, and use. Reading Research Quarterly, 53(3), 345-365.

Caine, R. N., \& Caine, G. (1990). Understanding a brain-based approach to learning and teaching. Educational leadership, 48(2), 66-70.

Camadan, F. (2018). Öğrenmenin doğası. Alim Kaya (Ed.). Eğitim Psikolojisi içinde (s. 110-131). Ankara: Pegem Yayıncılık.

Creswell, J. W. (2007). Qualitative inquiry \& research design choosing among five approaches. London: Sage Publications. 
Çelikten, M. (2006). Kültür ve öğretmen metaforları. Erciyes Üniversitesi Sosyal Bilimler Enstitüsü Dergisi, 21(2), 269-283.

Çulha Özbaş, B., \& Aktekin, S. (2013). Tarih öğretmen adaylarının tarih öğretmenliğine ilişkin inançlarının metafor analizi yoluyla incelenmesi. Eğitimde Kuram ve Uygulama, 9(3), 211228.

Dereobalı, N., \& Ünver, G. (2009). Okul öncesi öğretmenliği lisans programı Derslerinin öğretim elemanları tarafından genel bir bakış açısıyla değerlendirilmesi. İnönü Üniversitesi Eğitim Fakültesi Dergisi, 10(3), 161-181.

Domjan, M. (2014). The principles of learning and behavior. Nelson Education.

Dur, B. (2016). Metafor ve ekslibris. EX-LIBRIST-Uluslararası Ekslibris Dergisi, 3(5), 122-128.

Duman, B. (2011). Eğitim ve öğretimle ilgili temel kavramlar. Bilal Duman (Ed.) Öğretim ilke ve yöntemleri (2. Baskı) içinde (s.2-29). Ankara: Anı Yayıncılık.

Duman, B. (2013). Öğrenme-öğretme sürecindeki hata, yanılsama ve yanıltmacalara ilişkin öğrenci görüşleri. Sosyal ve Beşeri Bilimler Araştırmaları Dergisi, (25), 15-40.

Eisenhardt, D., \& Menzel, R. (2007). Extinction learning, reconsolidation and the internal reinforcement hypothesis. Neurobiology of learning and memory, 87(2), 167-173.

Ersoy, A. F. (2016). Fenomenoloji. Ahmet Saban ve Ali Ersoy (Ed. ). Eğitimde nitel araştırma desenleri içinde (s. 51-105). Ankara: Anı Yayıncllık.

Fırat, M., Kabakçı-Yurdakul, I., \& Ersoy, A. (2014). Bir eğitim teknolojisi araştırmasına dayalı olarak karma yöntem araştırması deneyimi. Eğitimde Nitel Araştırmalar Dergisi, 2(1), 65-86.

Fosnot, C. T., \& Perry, R. S. (1996). Constructivism: A psychological theory of learning. Constructivism: Theory, perspectives, and practice, 2, 8-33.

Geçer, A., \& Özel, R. (2012). İlköğretim fen ve teknoloji dersi öğretmenlerinin öğrenme-öğretme sürecinde yaşadıkları sorunlar. Kuram ve Uygulamada Eğitim Bilimleri, 12(3), 1-26.

Göğebakan-Yıldız, D. (2017). An analysis of attitudes and metaphor perceptions towards the course of curriculum development in education. Uluslararası Eğitim Programları ve Öğretim Çalışmaları Dergisi, 7(14), 113-130.

Gültekin, M. (2013). İlköğretim öğretmen adaylarının eğitim programı kavramına yükledikleri metaforlar. Eğitim ve Bilim, 38(169), 126-141.

Güneş, Y. İ., Sağdıç, F., \& Şimşek, C. L. (2018). Determination of the ctivities in econdary chool cience extbooks to upporting nquiry ased earning.Journal of Multidisciplinary Studies in Education, 2(2), 28-38.

Homer, R., Hew, K. F., \& Tan, C. Y. (2018). Comparing digital badges-and-points with classroom token systems: Effects on elementary school ESL students' classroom behavior and English learning. Journal of Educational Technology \& Society, 21(1), 137-151.

Işık, Ö. (2014). Sınıf öğretmeni adaylarının öğretmen, öğretme ve öğrenme kavramları ile ilgili metaforik algılarının yapılandırmacı yaklaşım açısından incelenmesi. (Unpublished Master Thesis). Pamukkale Üniversitesi, Denizli.

Jensen, D. (2006). Metaphors as a bridge to understanding educational and social contexts. International Journal of Qualitative Methods, 5(1), 36-54.

Kalyoncu, R. (2012). Visual arts teacher candidates' metaphors related to concept of" teaching. Mustafa Kemal Üniversitesi Sosyal Bilimler Enstitüsü Dergisi, 9(20), 471-484. 
Kanuka, H., Rourke, L., \& Laflamme, E. (2007). The influence of instructional methods on the quality of online discussion. British Journal of Educational Technology, 38(2), 260-271.

Koç, E. S. (2014). Sınıf öğretmeni adaylarının öğretmen ve öğretmenlik mesleği kavramlarına ilişkin metaforik algıları. Inönü Üniversitesi Eğitim Fakültesi Dergisi, 15(1), 47-72.

Kuzu, S., \& Demir, S. (2015). Öğretmen adayları için “öğretim ilke ve yöntemleri dersi öz yeterlilik ölçeği” nin geliştirilmesi. Mustafa Kemal Üniversitesi Sosyal Bilimler Enstitüsü Dergisi, 12(32), 401-415.

Mergendoller, J. R., Maxwell, N. L., \& Bellisimo, Y. (2006). The effectiveness of problem-based instruction: A comparative study of instructional methods and student characteristics. Interdisciplinary Journal of Problem-based Learning, 1(2), 49-69.

Merriam, S. B. (2009). Qualitative research (Third Edition). San Francisco: A Wiley Imprint.

Millı̂ Eğitim Bakanlığı Okul Öncesi Eğitim ve İlköğretim Kurumları Yönetmeliği (2014). 29072 sayılı Resmi Gazete. Retrieved from: http://www.resmigazete.gov.tr/eskiler/2014/07/20140726-4.htm

Milli Eğitim Bakanlığı (2017). Öğretmenlik Mesleği genel yeterlikleri. Öğretmen Yetiştirme ve Geliştirme Genel Müdürlüğü, Ankara. Retrieved from: http://oygm.meb.gov.tr/meb iys dosyalar/2017 12/11115355 YYRETMENLYK MESLEY Y GENEL YETERLYKLERY.pdf

Miller, S. I. (1987). Some comments on the utility of methaphorsfor educational theory and practicee, Educational Theory, 37(3) 219-227.

Muşta, M. C., \& Taşkaya, S. M. (2008). Sınıf öğretmenlerinin türkçe öğretim yöntemlerine ilişkin görüşleri. Elektronik Sosyal Bilimler Dergisi, 25, 240-251.

Ocak, G., Ocak, İ., Yllmaz, M., \& Mergen, H. H. (2012). İlköğretim öğretmenlerinin öğretim yöntem ve tekniklerine yönelik tutumları (Afyonkarahisar Örneği). İlköğretim Online, 11(2), 504519.

Okul Öncesi Eğitimi Programı (2013). Milli Eğitim Bakanlığı Temel Eğitim Genel Müdürlüğü, Ankara. Retrieved from: http://tegm.meb.gov.tr/dosya/okuloncesi/ooproram.pdf

Orlich, D. C., Harder, R. J., Callahan, R. C., Trevisan, M. S., \& Brown, A. H. (2012). Teaching strategies: A guide to effective instruction. Cengage Learning.

Öğretim Programları (2018). Milli Eğitim Bakanlığı Temel Eğitim Genel Müdürlüğü, Ankara. Retrieved from: http://mufredat.meb.gov.tr/Programlar.aspx

Öğretmen Yetiştirme Genel Müdürlüğü (2002). Öğretmen yeterlilikleri. Ankara: Milli Eğitim Basımevi.

Özdemir, S. M. (2012). Eğitim programı kavramına ilişkin öğretmen adaylarının metaforik algıları. Kuramsal Eğitimbilim Dergisi, 5(3), 369-393.

Özer, M. A. (2005). Etkin öğrenmede yeni arayışlar: İşbirliğine dayalı öğrenme ve buluş yoluyla öğrenme. Ahmet Yesevi Üniversitesi, Bilig, 35, 105-131.

Öztürk, Ç. (2004). Ortaöğretim coğrafya öğretmenlerinin öğretim yöntem ve teknikleri kullanabilme yeterlilikleri. Ahi Evran Üniversitesi Kırşehir Eğitim Fakültesi Dergisi, 5(2), 7583.

Patton, M. Q. (2014). Nitel araştırma ve değerlendirme yöntemleri. (Demir, S. B., Çev.) Ankara: PegemA. 
Pektaş, M., \& Kıldan, A. O. (2009). Farklı branşlardaki öğretmen adaylarının "öğretmen" kavramı ile ilgili geliştirdikleri metaforların karşılaștırılması. Erzincan Üniversitesi Eğitim Fakültesi Dergisi, 11(2), 270-288.

Richardson, V. (2005). Constructivist teaching and teacher education: Theory and practice. In Constructivist teacher education (pp. 13-24). Routledge.

Russell, H. (2007). Learning for being: an ontological and existential approach. International Journal of Lifelong Education, 26(4), 363-384.

Saban, A. (2004). Giriş düzeyindeki sınıf öğretmeni adaylarının “öğretmen” kavramına ilișkin ileri sürdükleri metaforlar. Türk Eğitim Bilimleri Dergisi, 2(2), 131-155.

Saban, A., Koçbeker, B. N., \& Saban, A. (2006). Öğretmen adaylarının öğretmen kavramına ilişkin algılarının metafor analizi yoluyla incelenmesi. Kuram ve Uygulamada Eğitim Bilimleri, 6(2), 461-522.

Saban. A. (2009). Öğretmen adaylarının öğrenci kavramına ilişkin sahip oldukları zihinsel imgeler. Türk Eğitim Bilimleri Dergisi, 7(2), 281-326.

Saban, A., \& Keleşoğlu, A. (2011). Bilgisayar öğretmeni adaylarının okul ve bilgisayar öğretmeni kavramlarına ilişkin zihinsel imgeleri. Kuram ve Uygulamada Eğitim Bilimleri, 11(1), 423446.

Saracaloğlu, A. S. \& Karasakaloğlu, N. (2011). Türkçe öğretmenlerinin öğretimde kullandıkları yöntem ve tekniklere ilişkin görüşleri. İlköğretim Online, 10(3), 951-960.

Sarıkaya, M., Güven, E., Göksu V., \& İnce- Aka, E. (2010). The impact of constructivist approach on students' academic achievement and retention of knowledge. Elementary Education Online, 9(1), 413-423.

Semerci, Ç. (2007). "Program geliştirme" kavramına ilişkin metaforlarla yeni ilköğretim programlarına farklı bir bakış. Sosyal Bilimler Dergisi, 31(2), 125-140.

Senemoğlu, N. (2007). Gelişim öğrenme ve öğretim. Kuramdan Uygulamaya. Ankara: Gönül Yayıncılık.

Soylu, Y. (2009). Sınıf öğretmen adaylarının matematik derslerinde öğretim yöntem ve teknikleri kullanabilme konusundaki yeterlilikleri üzerine bir çalışma. Mersin Üniversitesi Eğitim Fakültesi Dergisi, 5(1), 1-16.

Şahin, C.., \& Kartal, O. Y. (2013). Sınıf öğretmeni adaylarının sınıf öğretmeni yetiştirme programı hakkındaki görüşleri. Ușak Üniversitesi Sosyal Bilimler Dergisi, 2013(12), 164-190.

Şahin, B. (2013). Öğretmen adaylarının "matematik öğretmeni”,"matematik” ve "matematik dersi" kavramlarına ilişkin sahip oldukları metaforik algılar. Mersin Üniversitesi Eğitim Fakültesi Dergisi, 9(1), 313-321.

Tan, Ş. (2010). Öğretim ilke ve yöntemleri dersinde öğrencilerin akademik başarılarının yordanması. Uludağ Üniversitesi Eğitim Fakültesi Dergisi, 23(1), 239-266.

Tan, Ş. (2012). Öğretim ilke ve yöntemleri (8. baskı). Ankara: Pegem Akademi.

Tatar, N., \& Ceyhan, N. (2018). Fen bilgisi öğretmen adaylarının yapılandırmacı kurama dayalı öğretim uygulamalarının geliştirilmesi. İlköğretim Online, 17(1), 207-222.

Taşkın, Ş. Ç., \& Hacıömeroğlu, G. (2009, Mayıs). Öğretmen adaylarının meslek bilgisi dersleri üzerine bakış açıları. Sözlü bildiri, I. Uluslararası Türkiye Eğitim Araştırmaları Kongresi, Çanakkale. 
Tortop, H. S. (2013). Öğretmen Adaylarının Üniversite Hocası Hakkındaki Metaforları ve Bir Değerlendirme Aracı Olarak Metafor. Journal of Higher Education \& Science/Yüksekögretim ve Bilim Dergisi, 3(2), 153-160.

Wagener, A. E. (2017). Metaphor in Professional Counseling. Professional Counselor, 7(2), 144-154.

Williams, C. (2002). Learning on-line: a review of recent literature in a rapidly expanding field. Journal of Further and Higher Education, 26, 3, 263-272.

Yalçın, S., \& Avşar, A. Ş. (2014). Eğitim fakültesi meslek bilgisi derslerinin sıralama yargıları kanunuyla ölçeklenmesi. Eğitimde ve Psikolojide Ölçme ve Değerlendirme Dergisi, 5(2), 7990.

Yalçın-İncik, E. Y., \& Tanrıseven, I. (2012). Eğitim fakültesi öğretim elemanlarının ve öğretmen adaylarının öğrenci merkezli eğitime ilişkin görüşleri (Mersin Üniversitesi örneği). Mersin Üniversitesi Eğitim Fakültesi Dergisi, 8(3), 172-184.

Yalçın Wells, Ş. (2015). Görsel sanatlar öğretmeni adaylarının öğretmen ve sanatçı algısına ilişkin metafor analizi. Hacettepe Üniversitesi Eğitim Fakültesi Dergisi, 30(3), 160-175.

Yavuz, M., Özkaral, T., \& Yıldız, D. (2015). Uluslararası raporlarda öğretmen yeterlikleri ve öğretmen eğitimi. SDU International Journal of Educational Studies, 2(2), 60-71.

Yeşilpınar-Uyar, M. (2016). A need analysis study regarding to develop a schoolbased curriculum for teaching principles and methods course. Pegem Eğitim ve Öğretim Dergisi, 6 (1), 73-96.

Yeşilpınar-Uyar, M., \& Doğanay, A. (2017). Okul temelli yaklaşımla geliştirilen öğretim ilke ve yöntemleri dersi öğretim programının değerlendirilmesi. Uluslararası Eğitim Programları ve Öğretim Çalışmaları Dergisi, 14(2), 63-88.

Yeşilpınar-Uyar, M., \& Doğanay, A. (2018). A school-based curriculum development for the teaching principles and methods course. Croatian Journal of Education, 20(2), 621-672.

Yeşilyurt, E. (2013). Öğretmenlerin öğretim yöntemlerini kullanma amaçları ve karşılaştıkları sorunlar. Atatürk Üniversitesi Sosyal Bilimler Enstitüsü Dergisi, 17(1), 163-188.

Yıldırım, İ., \& Demir, S. (2016). Views about gamification based curriculum for the lesson of "teaching principles and methods". Uluslararası Eğitim Programları ve Öğretim Çalışmaları Dergisi, 2(6), 85-102.

Ylldız-Feyzioğlu, E. (2012). Science teachers' beliefs as barriers to implementation of constructivist-based education reform. Journal of Baltic Science Education, 11(4), 302-317.

Yılmaz, F., Göçen, S., \& Yılmaz, F. (2013). Öğretmen adaylarının öğretmen kavramına ilişkin algıları: Bir metaforik çalışma. Mersin Üniversitesi Eğitim Fakültesi Dergisi, 9(1), 151-164.

Young, M. R., Klemz, B. R., \& Murphy, J. W. (2003). Enhancing learning outcomes: the effects of instructional technology, learning styles, instructional methods, and student behavior. Journal of Marketing Education, 25(2), 130-142.

Yükseköğretim Kurulu. (2018). Yeni Öğretmen Yetiştirme Lisans Programları. Retrieved from: http://www.yok.gov.tr/web/guest/icerik/Liournal content/56 INSTANCE rEHF8BIsfYRx/10279/41807946 
In the writing process of the study titled "Pre-Service Teachers' Perceptions of the Teaching Principles and Methods Course: Metaphor Analysis", the rules of scientific, ethical and citation were followed; it was undertaken by the authors of this study that no falsification was made on the collected data. "Sakarya University Journal of Education Journal and Editor" had no responsibility for all ethical violations to be encountered, and all responsibility belongs to the authors and that the study was not submitted for evaluation to any other academic publishing environment. 
